\title{
Gastroparesis is associated with oxytocin deficiency, oesophageal dysmotility with hyperCCKemia, and autonomic neuropathy with hypergastrinemia

\author{
Julia Borg ${ }^{\dagger 1}$, Olle Melander ${ }^{\dagger 2}$, Linda Johansson ${ }^{\dagger 3,4}$, Kerstin Uvnäs-Moberg ${ }^{\dagger 4}$, \\ Jens F Rehfeld ${ }^{\dagger 5}$ and Bodil Ohlsson*1
}

\begin{abstract}
Address: ${ }^{1}$ Department of Clinical Sciences, Gastroenterology Division, Malmö University Hospital, Lund University, Lund, Sweden, ${ }^{2}$ Department of Clinical Sciences, Hypertension and Cardiovascular Disease, Malmö University Hospital, Lund University, Lund, Sweden, ${ }^{3}$ School of Life Sciences, University of Skövde, Skövde, Sweden, ${ }^{4}$ Department of Animal Environment and Health, Swedish University of Agriculture Sciences, Skara, Sweden and ${ }^{5}$ Department of Clinical Biochemistry, Rigshospitalet, University of Copenhagen, Copenhagen, Denmark

Email: Julia Borg - julia.faraj@med.lu.se; Olle Melander - olle.melander@med.lu.se; Linda Johansson - Linda.Johansson@his.se; Kerstin UvnäsMoberg - Kerstin.Uvnas-Moberg@fyfa.ki.se; Jens F Rehfeld - jens.f.rehfeld@rh.regionh.dk; Bodil Ohlsson* - bodil.ohlsson@med.lu.se

* Corresponding author †Equal contributors
\end{abstract}

Published: 25 February 2009

BMC Gastroenterology 2009, 9:17 doi:10.1186/147/-230X-9-17

This article is available from: http://www.biomedcentral.com/I47I-230X/9/17

(c) 2009 Borg et al; licensee BioMed Central Ltd.

This is an Open Access article distributed under the terms of the Creative Commons Attribution License (http://creativecommons.org/licenses/by/2.0), which permits unrestricted use, distribution, and reproduction in any medium, provided the original work is properly cited.

\begin{abstract}
Background: Gastrointestinal (GI) dysmotility and autonomic neuropathy are common problems among diabetics with largely unknown aetiology. Many peptides are involved in the autonomic nervous system regulating the $\mathrm{Gl}$ tract. The aim of this study was to examine if concentrations of oxytocin, cholecystokinin (CCK), gastrin and vasopressin in plasma differ between diabetics with normal function and dysfunction in GI motility.
\end{abstract}

Methods: Nineteen patients with symptoms from the GI tract who had been examined with gastric emptying scintigraphy, oesophageal manometry, and deep-breathing test were included. They further received a fat-rich meal, after which blood samples were collected and plasma frozen until analysed for hormonal concentrations.

Results: There was an increase in postprandial oxytocin plasma concentration in the group with normal gastric emptying $(p=0.015)$ whereas subjects with delayed gastric emptying had no increased oxytocin secretion $(p=0.114)$. Both $C C K$ and gastrin levels increased after the meal, with no differences between subjects with normal respective delayed gastric emptying. The concentration of vasopressin did not increase after the meal. In patients with oesophageal dysmotility the basal level of CCK tended to be higher $(P=0.05 \mathrm{I})$ and those with autonomic neuropathy had a higher area under the curve (AUC) of gastrin compared to normal subjects ( $P=$ 0.007).

Conclusion: Reduced postprandial secretion of oxytocin was found in patients with delayed gastric emptying, CCK secretion was increased in patients with oesophageal dysmotility, and gastrin secretion was increased in patients with autonomic neuropathy. The findings suggest that disturbed peptide secretion may be part of the pathophysiology of digestive complications in diabetics. 


\section{Background}

Many diabetic patients exhibit gastrointestinal (GI) dysmotility and autonomic neuropathy. Gastroparesis is the most well-described of the GI abnormalities, but oesophageal dysmotility is also common [1-3]. The aetiology to the dysmotility is largely unknown. Vagal or autonomic neuropathy, myopathy and damage to interstitial cells of Cajal (ICCs) have been proposed [4-6], but otherwise pathological findings have been sparse [7]. As many peptide hormones are involved in the regulation of the GI physiology, disturbed secretion of these peptides might contribute to a dysfunction.

Oxytocin and its receptor have recently been reported to be expressed in the GI tract $[8,9]$. Oxytocin is released in response to a fatty meal [10], which stimulates gastric emptying [11,12], and administration of a receptor antagonist during the meal delays the gastric emptying [13]. Cholecystokinin (CCK) and gastrin are released from endocrine cells in the upper GI tract in response to food, and they influence relaxation of the lower oesophageal sphincter (LOS), gastric acid secretion, gastric emptying, growth of gastric mucosa, contraction of the gallbladder, pancreatic growth, enzyme secretion, and intestinal motility $[14,15]$. Earlier studies have reported increased CCK and gastrin concentrations in plasma from diabetics with autonomic neuropathy [16-20], whereas patients without neuropathy showed normal concentrations, irrespective of GI function [17,19-21]. Recently, receptors for vasopressin, a peptide hormone homologous to oxytocin, have also been found in the GI tract [22], and vasopressin has been shown to affect the electrical rhythm in the human stomach $[23,24]$.

Although both oxytocin, CCK, gastrin, and vasopressin are involved in postprandial release and motility, the plasma concentrations of these hormones have not been thoroughly examined in relation to dysfunction in GI motility or autonomic neuropathy. The aim of the present study was therefore to examine whether the concentrations in plasma of these hormones from patients suffering from diabetes mellitus and GI symptoms are related to abnormalities in gastric emptying, oesophageal motility, and autonomic nerve function.

\section{Methods}

This study was performed according to the Helsinki declaration and approved by the Ethics Committee of Lund University. All patients were given written informed consent before entering the study.

\section{Subjects}

Consecutive patients at the Diabetes Clinic at Malmö University Hospital, who complained of symptoms from the digestive tract and were supposed to have gastroparesis, were invited to gastric emptying scintigraphy, oesophageal manometry, deep-breathing test reflecting the autonomic nerve function and continuous subcutaneous glucose concentration for $72 \mathrm{~h}$. Patients with regular use of opiates and other drugs influencing GI motility or hormonal release, or a marked reduced renal function were excluded. In addition, patients with severe retinopathy were excluded as some examinations demanded good eyesight. Twenty patients (10 women) with stable metabolic control accepted to participate [25].

\section{Basal examination procedure}

Gastric emptying scintigraphy was performed with the subjects in a semi-recumbent position as earlier described. A test meal was prepared by adding $30-50 \mathrm{Mbq}$ of technetium-99-labelled tin colloid to an egg, which was whipped in a glass cup while being heated in a water bath until coagulated. The scintigraphy half time $\left(T_{50}\right)$ was identified from the point at which this tendency line crossed the $50 \%$ value. Measurements of radionuclide were corrected for decay according to Collins et al. [26]. $\mathrm{T}_{50}>2$ standard deviation (SD) of healthy controls $(=70$ minutes) was considered abnormal [27].

Patients who fulfilled one or more pathological values in the oesophageal manometry of the following five criteria were considered to suffer from oesophageal dysmotility: 1/Absence of peristaltic contraction in the oesophagus, 2/ Mean peristaltic contraction amplitude $<30$ or $>200 \mathrm{~mm}$ $\mathrm{Hg}$ in the oesophagus, 3/Percentage of simultaneous, non-propulsive peristaltic waves in the oesophagus $>10$, $4 /$ Speed of the peristaltic wave $<3$ or $>6 \mathrm{~cm} / \mathrm{sec}$ in the distal oesophagus, $5 /$ Resting pressure in the LOS $<10$ or $>30$ $\mathrm{mm} \mathrm{Hg}$. Normal peristaltic activity was defined as propulsive contraction waves with peak amplitudes between 30$200 \mathrm{mmHg}$ and a speed between $3-6 \mathrm{~cm} / \mathrm{sec}$ [28].

The expiratory/inspiratory (E/I) ratio was calculated from the mean value of the longest R-R interval during expiration and the shortest R-R interval during inspiration. This is an established test of vagal, parasympathetic nerve function [29]. All test results were expressed in age-related values and an age-related value below -1.64 SD was considered abnormal [30].

\section{Patient characteristics}

Out of the 20 patients included, 19 were further included in the present study. All patients were insulin-treated; 17 with type 1 and 2 with type 2 diabetes. The 19 patients were investigated with gastric emptying scintigraphy, 17 with a deep-breathing test and 13 with oesophageal manometry. The reason that not all the patients performed all the examinations, depended on that the patients had to perform several different examinations, and thought it was too much to go through everything. Ten of 19 patients 
had delayed gastric emptying (221 [116.0-362.5] minutes compared to 35.0 [23.5-44.5] minutes in patients with normal emptying) and 7 out of 13 patients showed dysmotility of the oesophagus in the form of aperistalsis and/or simultaneous contractions. Nine of 17 showed abnormal expiration/inspiration (E/I) quote as a sign of autonomic neuropathy. There were no correlations between disturbances in GI or autonomic function (data not shown). The distribution of the GI symptoms, which did not differ between groups except for abdominal fullness which correlated to delayed emptying, are presented in an earlier study [25]. There was no difference in sex, age, duration of diabetes, HbA1c or glucose levels between the groups of normal and abnormal function of respective parameter [25].

When scrutinizing the medical records, one was found to suffer from pernicious anaemia, whereas all the others had normal values of haemoglobin and cobalamines.

\section{Experimental procedure}

All subjects were fasted overnight. In the morning they were given a fat-rich meal containing $150 \mathrm{~g}$ cream and 150 $\mathrm{g}$ water. This generated $60 \mathrm{~g}$ fat and $561 \mathrm{kcal}$. This meal corresponds to the same content of fat as earlier used to evoke CCK and oxytocin secretion [10]. Blood samples were taken through an intravenous catheter $10 \mathrm{~min}$ and immediately before the meal, as well as $10,20,30,45,60$, 90, 120, 150 and 180 min after the meal. All blood samples consisted of $8.0 \mathrm{ml}$ whole blood drawn into iced heparinised tubes. The plasma was separated and frozen at $-20^{\circ} \mathrm{C}$ immediate after the experiment.

\section{Plasma analyses \\ Oxytocin}

Oxytocin levels were determined using Correlate-EIA ${ }^{\mathrm{TM}}$ Oxytocin Enzyme Immunoassay Kit (Assay designs, Inc. Ann Arbor, USA) according to the instructions from the manufacturer. Included on each plate were standards and controls as recommended. Plasma samples were diluted five times in assay buffer before analysis. The washing procedure was performed using an Anthos Fluido micro plate washer (Anthos Fluido, Salzburg, Austria) and the absorbance was read using a Multiscan (R) Ex micro plate photometer (Thermo Electron Corporation, Vantaa, Finland). The colour development of the samples was read at 405 $\mathrm{nm}$ with background correction at $620 \mathrm{~nm}$. The Ascent software was used for creation of standard curves, curve fitting and calculation of concentrations (Ascent software version 2.6 for iEMS Reader MF and multiscan, Vantaa, Finland).

\section{Cholecystokinin (CCK) and gastrin}

The concentrations of CCK in plasma were measured using a highly accurate radioimmunoassay, as previously described [31]. The limit of detection for this assay is 0.1 $\mathrm{pmol} / \mathrm{l}$ with intra-assay and interassay variations of less than $5 \%$ and $15 \%$, respectively, at both 3.7 and $15 \mathrm{pmol} /$ l concentrations. The concentration of gastrin in plasma was also assayed by radioimmunoassay using rabbit antibody 2604-8 [32] and 125I-iodinated human gastrin-17 as tracer [33]. The detection limit was $5 \mathrm{pg} / \mathrm{ml}$ and the interassay coefficient of variation was below $8 \%$ in the range $10-100 \mathrm{pg} / \mathrm{ml}$.

\section{Vasopressin}

The concentration of vasopressin in plasma was analyzed by a radioimmunoassay described by Rooke \& Baylis [34].

\section{Statistical analyses}

The concentrations are given as median [interquartile ranges, IQR]. The basal value is the mean of the two samples taken before the meal. Peak value is the highest concentration measured in plasma after the meal. The area under the curve (AUC) was calculated for oxytocin, CCK and gastrin from all samples taken. The Mann-Whitney $U$ test was used for comparisons between groups and the Wilcoxon signed test for comparisons between basal and peak levels within the group. The Spearman test was used for correlations between different parameters. $\mathrm{P}<0.05$ was considered statistical significant.

\section{Results \\ Hormone concentrations in plasma in relation to gastric emptying}

There was a significant increase in postprandial oxytocin concentrations as compared to baseline in the group of patients with normal gastric emptying. In contrast, patients with delayed gastric emptying showed no increase of oxytocin secretion in response to the meal (Fig 1). However, the AUC did not differ between the two groups (16952.7 [8396.3-44792.2] and 37425.1 [14724.6-63779.9], respectively; $\mathrm{p}=0.400)$, as did either basal or peak values (Fig 1). The oxytocin concentration in plasma in the two groups over time is shown in Fig 2. CCK and gastrin secretions were both increased compared to baseline in response to the meal. There were no differences in the secretion of these hormones between patients with normal versus delayed gastric emptying (Fig 3 and 4). The plasma concentration of vasopressin was not increased after the meal between patients with normal gastric emptying (0.7 [0.5-0.8] during basal conditions compared to $0.6[0.5-1.0] \mathrm{pmol} / \mathrm{l}$ postprandial; $\mathrm{p}=$ 0.285 ), why this hormone was not studied in subjects with delayed gastric emptying. There were no significant correlations between the plasma concentrations of the different hormones (data not shown). 

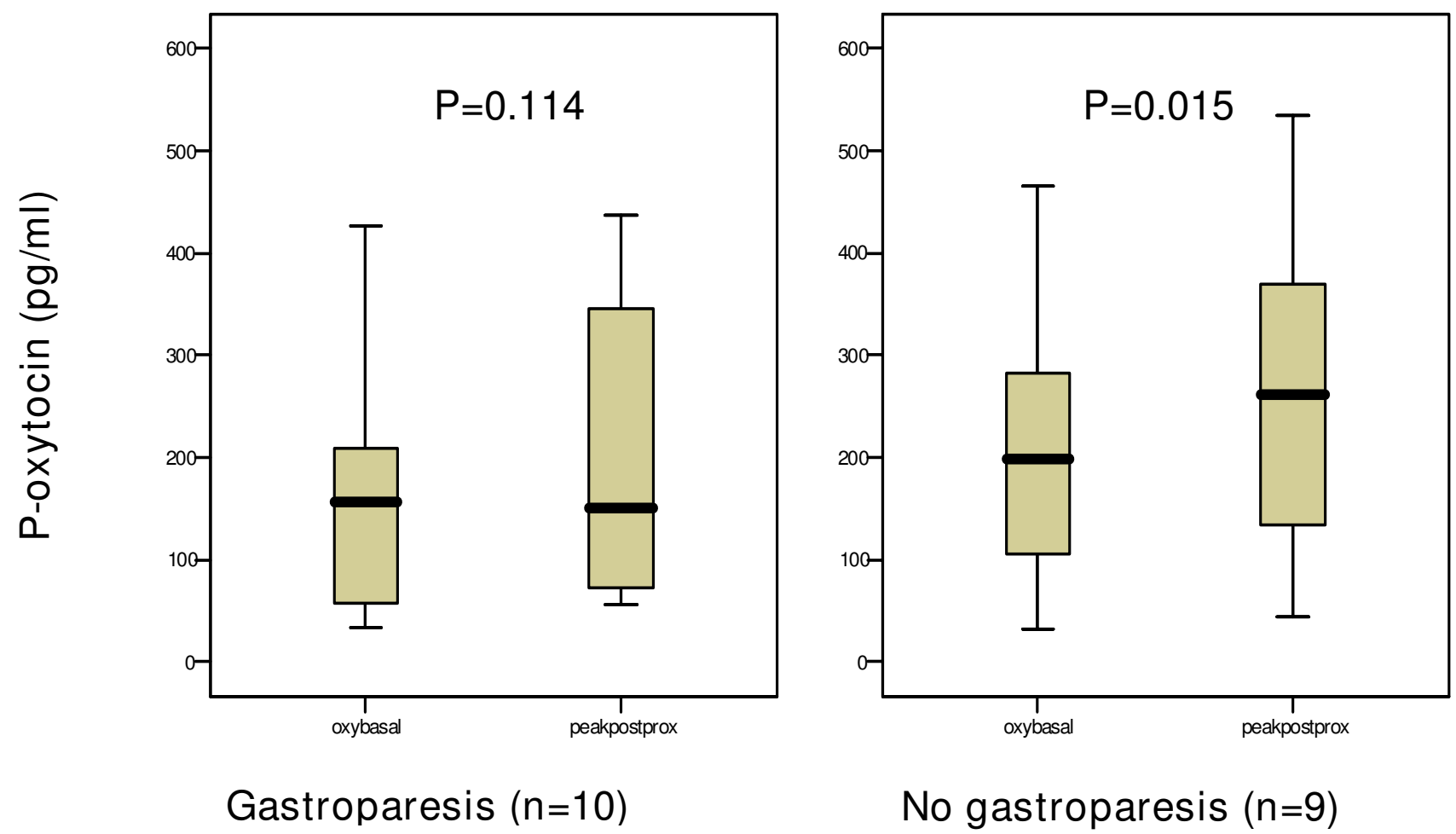

No gastroparesis $(n=9)$

\section{Figure I}

The plasma concentration of oxytocin (oxy) at basal conditions and peakpostprandially, in subjects with and without gastroparesis. The basal value is the mean of the two samples taken before the meal. Peak value is the highest level measured in plasma after the meal. Median [IQR]. Wilcoxon signed test. There was no difference in basal or peak values between the groups, Mann-Whitney U-test.

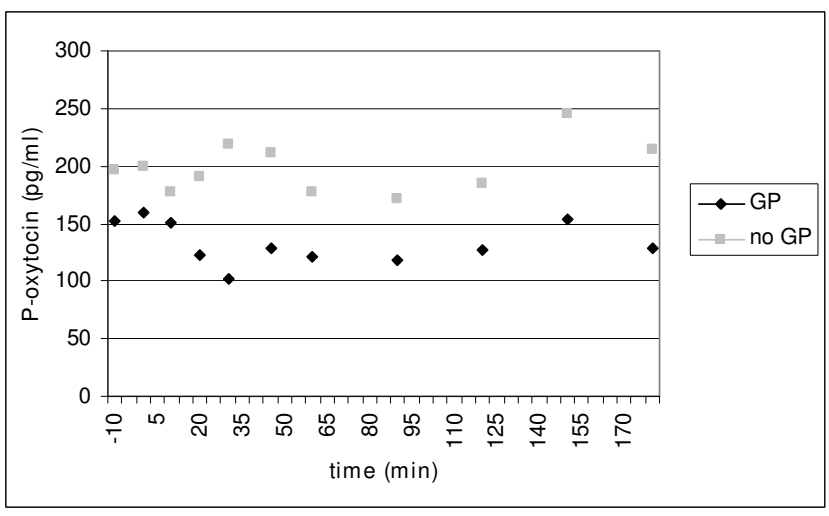

\section{Figure 2}

The fluctuations of the mean oxytocin concentration in plasma postprandial, in subjects with and without gastroparesis. GP = gastroparesis, $n=10$, no gastroparesis, $\mathrm{n}=9$. There was no statistical significant difference between the groups. Mann Whitney U-test.

\section{Hormone concentrations in plasma in relation to oesophageal dysmotility}

The basal concentrations of CCK tended to be higher in the group of patients with aperistalsis and/or simultaneous contractions compared to those with normal oesophageal motility (Fig 5), whereas there was no difference in the peak concentrations measured after the meal (3.6 [2.8-5.3] and $3.4[2.6-8.6] \mathrm{pmol} / \mathrm{l}$, respectively; $\mathrm{p}=$ $0.604)$, nor in the AUC (377.8 [257.8-548.0] and 273.0 [230.6-419.2], respectively; $\mathrm{p}=0.366)$.

The LOS pressure correlated negatively to the CCK concentrations $\left(r_{s}=-0.679, p=0.022\right)$. None of the other hormones correlated with the oesophageal function (data not shown).

\section{Hormone concentrations in plasma in relation to autonomic neuropathy}

Patients with autonomic neuropathy had significantly higher concentrations of gastrin in plasma than patients without neuropathy. There were differences both in the 

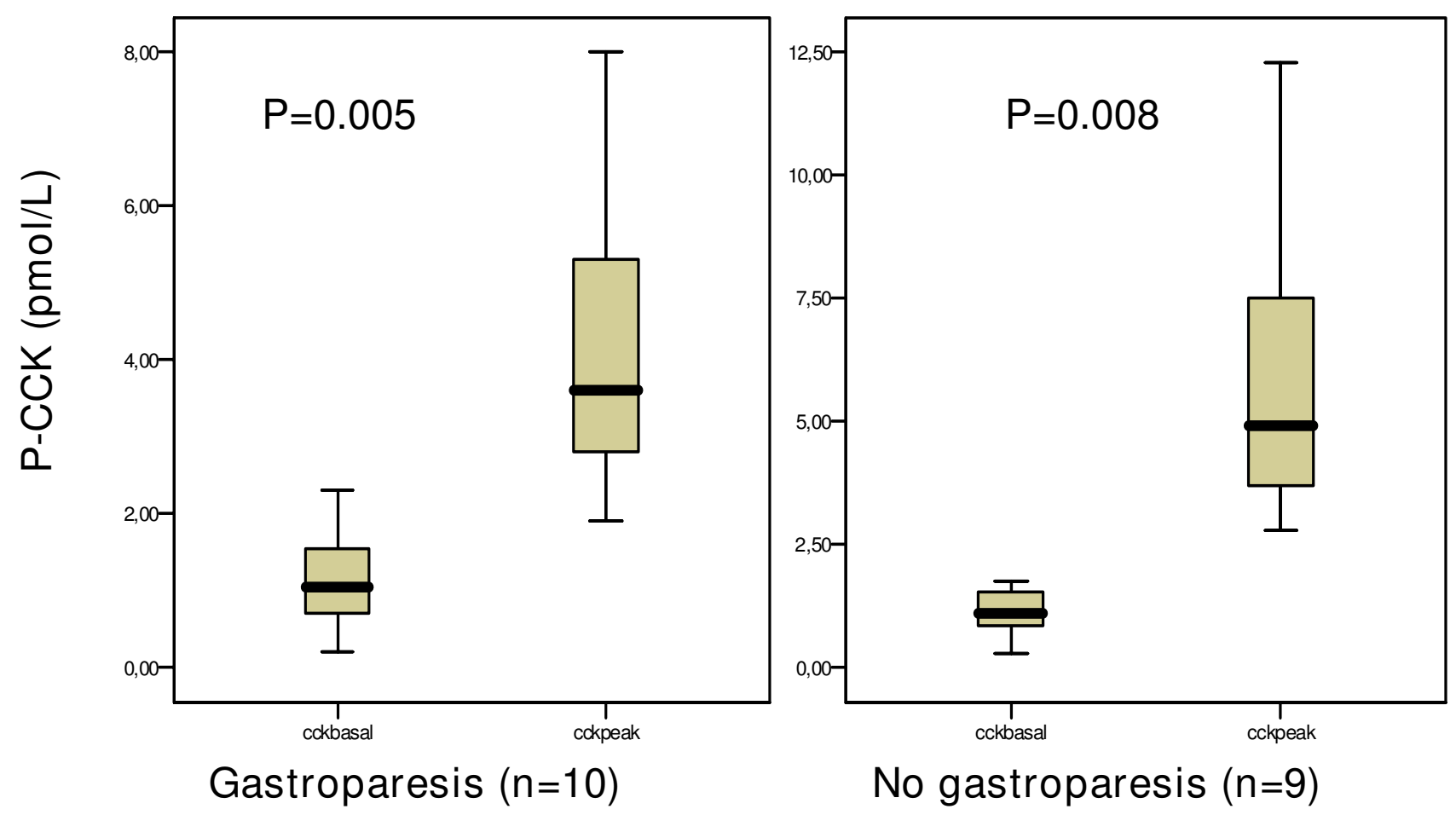

\section{Figure 3}

The plasma concentration of cholecystokinin (CСK) at basal conditions and peakpostprandially, in subjects with and without gastroparesis. The basal value is the mean of the two samples taken before the meal. Peak value is the highest level measured in plasma after the meal. Median [IQR]. Wilcoxon signed test. There was no difference in basal or peak values between the groups, Mann-Whitney U-test.

AUC (Fig 6) and the peak values (22.0 [15.5-57.0] and $13.5[11.2-15.0] \mathrm{pmol} / \mathrm{l}$, respectively; $\mathrm{p}=0.046)$. There were no differences in oxytocin or CCK peak concentrations between the groups (181.5 [73.6-449.5] and 211.4 $[139.7-346.8] \mathrm{pg} / \mathrm{ml}$ oxytocin, respectively; $\mathrm{p}=0.888$; and 4.4 [3.3-6.6] and 3.4 [2.8-5.6] pmol/1 CCK, respectively; $\mathrm{p}=0.423$ ). Neither was there any difference in the AUC between those with or without autonomic neuropathy (29502.5 [9377.3-65353.4] and 30536.7 [10605.156321.3] for oxytocin, respectively; $\mathrm{p}=0.743$; and 423.0 [274.2-661.0] and 305.1 [258.4-369.0] for CCK, respectively; $\mathrm{p}=0.195$ ).

\section{Discussion}

This is the first study to show that patients with diabetes mellitus and normal gastric emptying rate have an increased release of oxytocin postprandially, whereas patients with delayed gastric emptying rate have no such increased postprandial secretion. Instead, patients with delayed gastric emptying tended to have a decrease in oxytocin concentrations with less fluctuation over time. There was no difference in CCK or gastrin secretion related to gastric emptying, but patients with oesophageal dysmotility tended to have higher basal CCK concentrations, and in autonomic neuropathy gastrin concentrations were increased compared to normal subjects.

Oxytocin was long thought to be a hormone primarily involved in parturition and suckling. We now know that oxytocin has diverse effects throughout the human body, for example on the release of atrial natriuretic peptide and in endothelial and smooth muscle cells in blood vessels $[35,36]$. In normal subjects, oxytocin expression has been found in the gut $[8,9]$, where it is secreted after a meal [10] and stimulates colonic activity [37]. It has further been demonstrated that systemic administration of oxytocin leads to enhanced gastric emptying $[11,12]$ and that the oxytocin receptor antagonist atosiban delays gastric emptying significantly [13]. The prokinetic effect of oxytocin on the gut has been assumed to be similar to the one in uterine myometrium and mammary myoepitheal cells; i.e. intracellular release of $\mathrm{Ca} 2+$ which leads to muscle contraction via myosin light kinase activity [38]. 


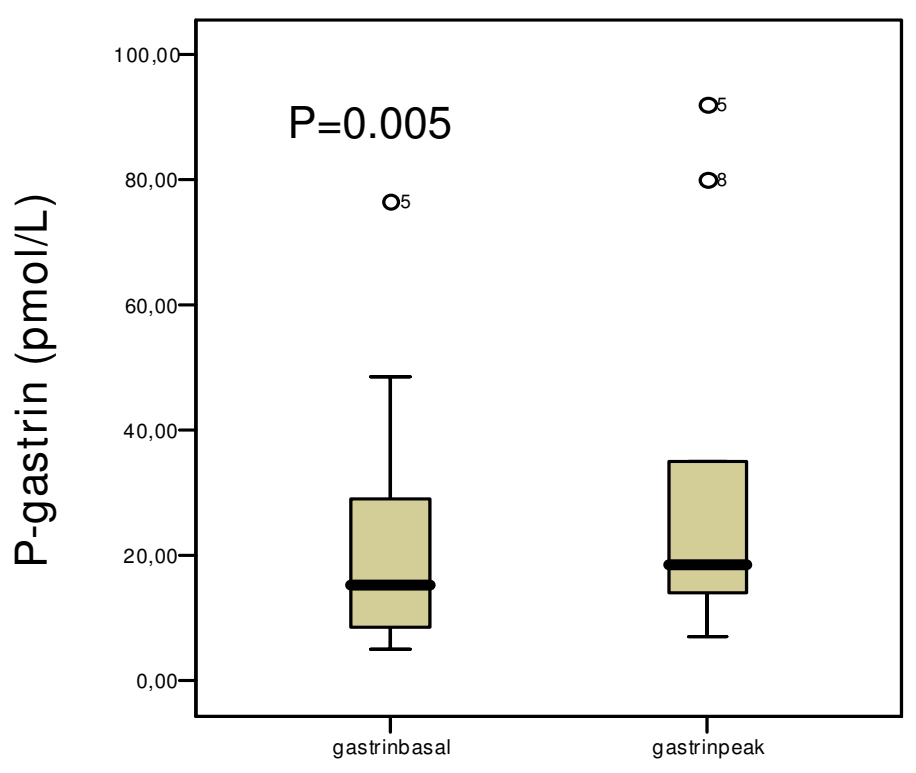

Gastroparesis $(n=10)$

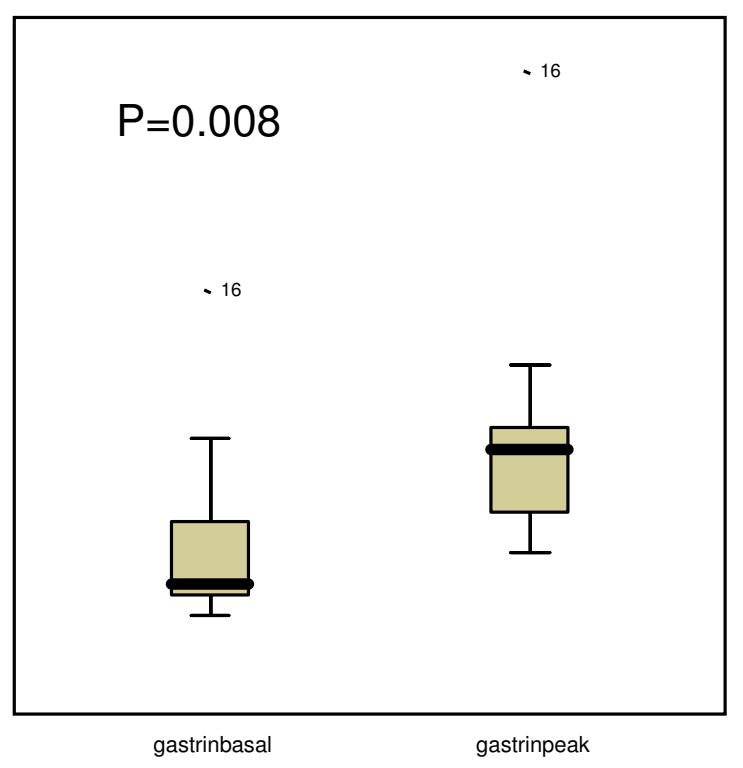

No gastroparesis $(n=9)$

\section{Figure 4}

The plasma concentration of gastrin at basal conditions and postprandially, in subjects with and without gastroparesis. The basal value is the mean of the two samples taken before the meal. Peak value is the highest level measured in plasma after the meal. Median [IQR]. Wilcoxon signed test. There was no difference in basal or peak values between the groups, Mann-Whitney U-test.

Oxytocin concentrations were higher in this study than in earlier studies [10]. This depends on that ELIZA in general give higher values than radioimmunoasays (RIA). The two peaks in oxytocin secretion in diabetics without gastroparesis are similar to those seen in healthy subjects after a meal [10]. This could be explained by a rapid release of oxytocin from the gut and a later one from the hypophysis. The oxytocin release from the hypophysis is due to an effect of CCK on afferent vagal nerves and appears with some time delay after that the meal has induced CCK secretion $[10,39]$. This hypothesis is strengthened by the fact that this dual oxytocin release was not seen after intravenous CCK injection $[10,40]$. The reduced postprandial oxytocin secretion in subjects with delayed gastric emptying could be part of the pathogenesis in gastroparesis. It is still unknown whether this disturbance is primary or secondary to gastroparesis or depends on dysfunction in the CCK-oxytocin interaction, intrinsic gastric nerves, the vagal nerve, or in regulation of other hormones. Nevertheless, a substitution with oxytocin postprandially may regain the gastric dysfunction and should be tested.

Cholecystokinin is produced in endocrine I-cells in the upper part of the small intestine and has an important role in relaxation of the LOS and gastric emptying [14]. The oesophageal dysmotilities in patients in this study were aperistalsis and simultaneous contractions [25]. We do not know why they are associated with hyperCCKemia. It may be due to abnormal neural reflexes affecting the CCK release, or to concomitant small intestinal dysmotility delaying the clearing of nutrients from the small intestine with ensuing increase in CCK secretion [41]. In our earlier study we saw that patients with oesophageal dysmotility also had delayed blood glucose response after a meal [25], a finding in agreement with this discussion.

In a previous study Glasbrenner [19] found CCK to be elevated in plasma from patients with autonomic neuropathy. Another study showed significantly lower CCK concentrations in diabetics without autonomic neuropathy compared to healthy controls [42]. It is possible that the patients in Glasbrenner's study [19] with hyperCCKemia also suffered from oesophageal dysmotility, which could explain their results.

Gastrin is released in response to food intake and acts in the stomach by stimulation of acid secretion and mucosal growth [15]. This process is regulated by a negative feedback mechanism to prevent excessive acid secretion. In 


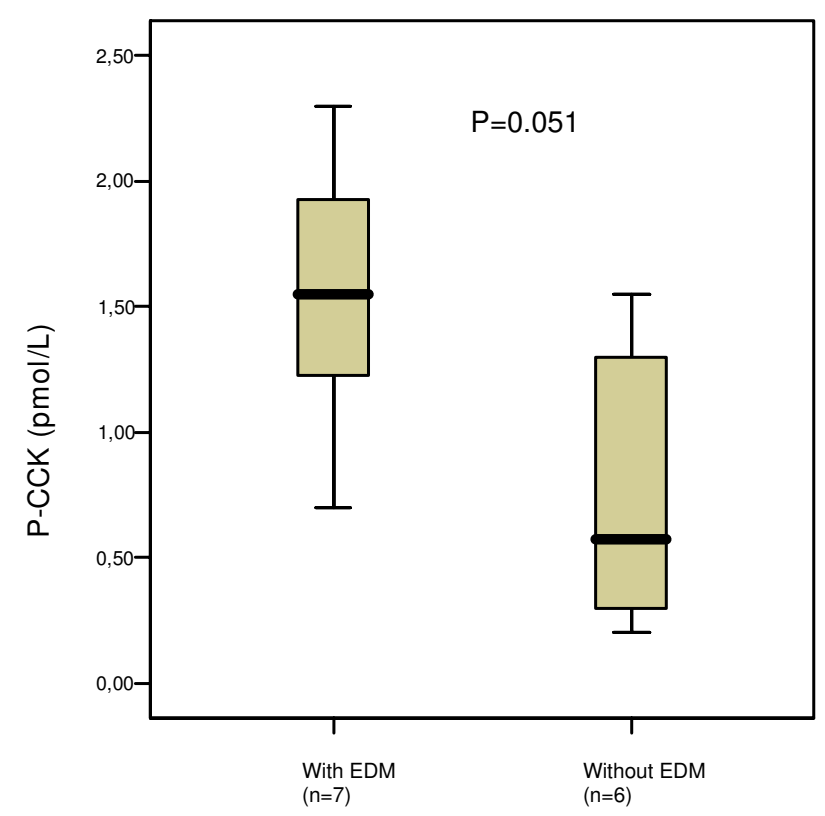

Figure 5

The plasma concentration of cholecystokinin (CCK) at basal conditions, in subjects with and without oesophageal dysmotility (EDM). The basal value is the mean of the two samples taken before the meal. Median [IQR]. Mann Whitney $U$ test.

accordance with earlier studies we found that patients with autonomic neuropathy have significantly higher concentrations of gastrin in plasma [16-18,20]. The elevated gastrin concentrations cannot be explained by atrophic gastritis in this study since only one subject had this condition. However, the elevation could be a result of a disturbed feedback mechanism due to neuropathy in the stomach [6], vagal neuropathy $[16,17]$, an increased quantity of gastrin cells in the stomach [43], reduced number of somatostatin cells [44], or hyperglycaemia [45].

Vasopressin is homologous to oxytocin. Recently it has been shown that the vasopressin receptor is expressed throughout the GI tract [22]. We measured the concentration of vasopressin after a meal in patients with normal gastric emptying and found no increased secretion compared to basal conditions. As vasopressin thus not seems to be an important peptide in relation to a meal, we decided not to measure vasopressin in the rest of the patients.

\section{Conclusion}

We have shown that patients with diabetes mellitus and normal gastric emptying have a postprandial increase in oxytocin secretion, whereas oxytocin secretion is impaired

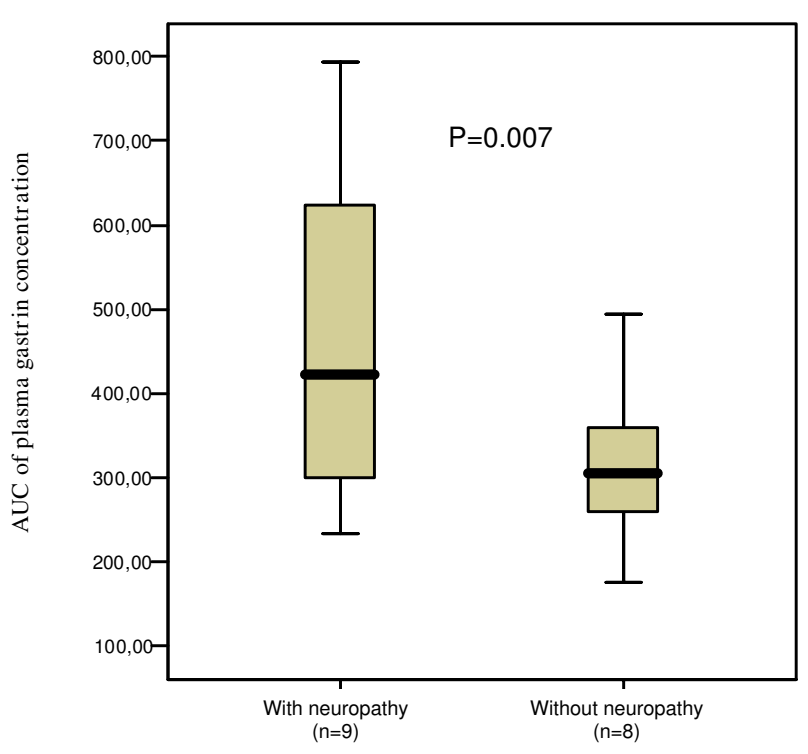

Figure 6

Area under curve (AUC) of plasma gastrin concentration in subjects with and without autonomic neuropathy. Median [IQR]. Mann Whitney $U$ test.

in subjects with delayed gastric emptying. We could not find a difference in postprandial CCK or gastrin secretion in patients with and without delayed gastric emptying. However, in patients with oesophageal dysmotility the basal concentration of CCK tended to be higher, and in patients with autonomic neuropathy the gastrin concentrations were increased compared to normal subjects. In the light of our earlier research on oxytocin and its role for a normal GI function [11,12,33-37], the role of oxytocin treatment in gastroparesis has to be further evaluated.

\section{Abbreviations}

AUC: area under the curve; CCK: Cholecystokinin; GI: gastrointestinal; ICCs: Interstitial cells of Cajal; LOS: lower oesophageal sphincter; $\mathrm{SD}$ : standard deviation; $\mathrm{T}_{50}$ : scintigraphy half time.

\section{Competing interests}

The authors declare that they have no competing interests.

\section{Authors' contributions}

JB has substantial contributions to analysis and interpretion of data and mainly drafting the manuscript. OM has contributed to conception and design, acquisition of data, analysis and interpretion of data and has been involved in revising the manuscript critically. LJ, KUM and JFR have contributed to analysis and interpretion of data and have been involved in revising the manuscript critically. BO has contributed to conception and design, acquisition of data, 
analysis and interpretion of data and has been involved in drafting the manuscript. All authors have read and approved the final manuscript.

\section{Acknowledgements}

This study was supported by grants from the Development Foundation of Region Skane, the Magnus Bergvall Foundation, and the Crafoord Foundation. We want to express our gratitude and appreciation to Professor Göran Sundkvist who initiated this study, but died during the course.

\section{References}

I. Wegener M, Borsch G, Schaffstein J, Luerweg C, Lewerkus F: Gastrointestinal transit disorders in patients with insulin treated diabetes mellitus. Dig Dis 1990, 8:23-26.

2. Horowitz M, Maddox AF, Wishart JM, Harding PE, Chatterton BE Shearman DJC: Relationships between oesophageal transit and solid and liquid gastric emptying in diabetes mellitus. Eur Nucl Med I99I, I 8:229-234

3. Faraj J, Melander O, Sundkvist G, Olsson R, Thorson O, Ekberg $O$ Ohlsson B: Oesophageal dysmotility, delayed gastric emptying and gastrointestinal symptoms in patients with diabetes mellitus. Diabet Med 2007, 24:1235-1239.

4. Clark WD, Nowak VT, Diabetic gastroparesis: What to do when gastric emptying is delayed. Postgrad Med 1994, 95: 195-204.

5. Ejskjaer NT, Bradley JL, Buxton-Thomas MS, Edmonds ME, Howard EK, Purewal T, Thomas PK, Watkins PJ: Novel surgical treatment and gastric pathology in diabetic gastroparesis. Diabet Med 1999, I 6:488-495.

6. Ordog T, Takayama I, Cheung WK, Ward SM, Sanders KM: Remodeling of networks of interstitial cells of Cajal in a murine model of diabetic gastroparesis. Diabetes 2000, 49:|73|-|739.

7. Yoshida MM, Schuffler MD, Sumi SM: There are no morphologic abnormalities of the gastric wall or abdominal vagus in patients with diabetic gastroparesis. Gastroenterology 1988 94:907-9|4

8. Monstein H-J, Grahn N, Truedsson M, Ohlsson B: Oxytocin and oxytocin receptor mRNA expression in the human gastrointestinal tract: A polymerase chain reaction study. Reg Pept 2004, I 1 9:39-44.

9. Ohlsson B, Truedsson M, Djerf $P$, Sundler $F$ : Oxytocin is present throughout the human gastrointestinal tract. Reg Pept 2006 I35:7-II.

10. Ohlsson B, Forsling ML, Rehfeld JF, Sjölund K: Cholecystokinin leads to increased oxytocin secretion in healthy women. Eur J Surg 2002, I68: I|4-|| I8.

II. Hashmonai M, Torem S, Argov S, Barzilai A, Schramek A: Prolonged post-vagotomy gastric atony treated by oxytocin. $\mathrm{Br} J$ Surg 1979, 66:550-55।.

12. Petring OU: The effect of oxytocin on basal and pethidineinduced delayed gastric emptying. $\mathrm{Br} J$ Clin Pharmacol 1989, 28:329-332.

13. Ohlsson B, Björgell O, Ekberg O, Darwiche G: The oxytocin/vasopressin receptor antagonist atosiban delays the gastric emptying of a semisolid meal compared to saline in human. $B M C$ Gastroenterology 2006, 6: II.

14. Grider JR: Role of cholecystokinin in the regulation of gastrointestinal motility. I Nutr 1994, I 24: I334S-I339S.

15. Rehfeld JF: The new biology of gastrointestinal hormones. Physiol Rev 1998, 78(4): 1087-I I08.

16. Sasaki H, Nagulesparan M, Dubois A, Straus E, Samloff IM, Lawrence WH, Johnson GC, Sievers ML, Unger RH: Hypergastrinemia in obese noninsulin-dependent diabetes: A possible reflection of high prevalence of vagal dysfunction. I Clin Endocrin Metab | 983, 56(4):744-750.

17. Kanatsuka A, Osegawa M, An T, Suzuki T, Hashimoto N, Makino $H$ Augmented gastrin responses in diabetic patients with vagal neuropathy. Diabetologia 1984, 26:449-452.

18. Nakamura T, Takebe K, Imamura K-I, Miyazawa T, Ishii M, Kudoh K, Terada A, Machida K, Kikuchi H, Kasai F, Tandoh Y, Arai Y, Yamada $\mathrm{N}$ : Decreased gastric secretory functions in diabetic patients with autonomic neuropathy. Tohoku I Exp Med 1994 I 73:199-208.
19. Glasbrenner B, Dominguez-Munoz E, Riepl RL, Vetsi A, Malfertheiner $P$ : Cholecystokinin and pancreatic polypeptide release in diabetic patients with and without autonomic neuropathy. Dig Dis Sci 1995, 40:406-4II.

20. Migdalis I, Thomaides T, Chairopoulos C, Kalogeropoulou C, Charalabides J, Mantzara F: Changes of gastric emptying rate and gastrin levels are early indicators of autonomic neuropathy in type II diabetic patients. Clin Auton Res 200 I, I I:259-263.

21. Frank JW, Saslow SB, Camilleri M, Thomforde GM, Dinneen S, Rizza RA: Mechanism of accelerated gastric emptying of liquids and hyperglycemia in patients with type II diabetes mellitus. Gastroenterology 1995, 109:755-765.

22. Monstein HJ, Truedsson M, Ryberg A, Ohlsson B: The vasopressin receptor mRNA expression in non-tumor tissues of the human gastrointestinal tract. Eur Surg Res 2007, 40:34-40.

23. Caras SD, Soykan I, Beverly V, Lin Z, McCallum RW: The effect of intravenous vasopressin on gastric myoelectrical activity in human subjects. Neurogastroenterol Motil 1979, 9:|5|-|56.

24. Kim MS, Chey WD, Owyang C, Hasler WL: Role of plasma vasopressin as a mediator of nausea and gastric slow wave dysrythmias in motion sickness. Am J Physiol 1997, 272:G853-G862.

25. Ohlsson B, Melander O, Thorson O, Olsson R, Ekberg O, Sundkvist G: Oesophageal dysmotility, delayed gastric emptying and autonomic neuropathy correlate to disturbed glucose homeostasis. Diabetologia 2006, 49:2010-2014.

26. Collins PJ, Horowitz M, Cook DJ, Harding PE, Shearman DJ: Gastric emptying in normal subjects: a reproducible technique using a single scintillation camera and computer system. Gut 1983 , 24: I| | 7- II 25.

27. Hanson M, Lilja B: Gastric emptying in smokers. Scand J Gastroenterol 1987, 22: I 102-I I04.

28. Spechler SJ, Castell DO: Classification of oesophageal motility abnormalities. Gut 200I, 49:|45-|5|.

29. Sundkvist G, Almér L-O, Lilja B: Respiratory influence on heart rate in diabetes mellitus. $\mathrm{Br}$ Med J 1979, I:924-925.

30. Forsen A, Kangro M, Sterner G, Norrgren K, Thorsson O, Wollmer $P$, Sundkvist G: A I4-year prospective study of autonomic nerve function in type I diabetic patients: association with neuropathy. Diabet Med 2004, 2 I:852-858.

31. Rehfeld JF: Accurate measurement of cholecystokinin in plasma. Clin Chem 1998, 44:991-1001.

32. Rehfeld JF, Stadil F, Rubin B: Production and evaluation of antibodies for the radioimmunoassay of gastrin. Scand J Clin Lab Invest 1972, 30:221-232.

33. Stadil F, Rehfeld JF: Preparation of $\mathbf{1 2 5}$ |-labelled human gastrin for radioimmunoanalysis. Scand J Clin Lab Invest 1972, 30:361-369.

34. Rooke $\mathrm{P}$, Baylis $\mathrm{PH}$ : A new sensitive radioimmunoassay for plasma arginine vasopressin. J Immunoassay 1982, 3: I I5-I3 I.

35. Gutkowska J, Jankowski M, Lambert C, Mukaddam-Daher S, Zingg $\mathrm{HH}$, McCann SM: Oxytocin releases atrial natriuretic peptide by combining with oxytocin receptors in the heart. Proc Natl Acad Sci 1979, 94: I I704-I I 709.

36. Thibonnier M, Conarty DM, Preston JA, Plesnicher CL, Dweik RA Erzurum SC: Human vascular endothelial cells express oxytocin receptors. Endocrinology 1999, 140:1301-1309.

37. Ohlsson B, Ringström G, Abrahamsson H, Simrén M, Björnsson ES: Oxytocin stimulates colonic motor activity in healthy women. Neurogastroenterol Mot 2004, I 6:233-240.

38. Gimpl G, Fahrenholz F: The oxytocin receptor system: structure, function, and regulation. Physiol Rev 200I, 8I:629-683.

39. Verbalis JG, McCann MJ, McHale CM, Stricker EM: Oxytocin secretion in response to cholecystokinin and food: Differentiation of nausea from satiety. Science $1986,232: 1417-1419$.

40. Ohlsson B, Rehfeld JF, Forsling ML: Oxytocin and cholecystokinin secretion in women with colectomy. BMC Gastroenterology 2004, 4:25

4I. Sjölund K, Bartosik I, Lindberg G, Scheja A, Wildt M, Åkesson A: Small intestinal 4 manometry in patients with systemic sclerosis. Eur / Gastroenterol Hepatol 2005, I 7: | 205-1212.

42. Bucceri $A M$, Calogero $A E$, Brogna $A$ : Gallbladder and gastric emptying: relationship to cholecystokinemia in diabetics. Eur J Int Med 2002, 13:123-128.

43. Pinto HC, Portela-Gomes GM, Grimelius L, Kohnert KD, de Sousa JC, Albuquerque MA: The distribution of endocrine cell types of 
the gastrointestinal mucosa in genetically diabetic $(\mathrm{db} / \mathrm{db})$ mice. Gastroenterology 1995, 108:967-974.

44. Chen D, Uribe A, Håkanson R, Sundler F: Somatostatin cells in the oxyntic mucosa of hypo- or hypergastrinemic rats. Scand J Gastroenterol 1992, 27:479-482.

45. Gultekin F, Gurbilek M, Vatansev H, Yasar S, Akoz M, Ozturk M: Effect of oral glucose loading on serum gastrin level in pregnant and non-pregnant women. Croat Med J 200I, 42:I5I-I 55.

\section{Pre-publication history}

The pre-publication history for this paper can be accessed here:

http://www.biomedcentral.com/1471-230X/9/17/pre pub

Publish with Bio Med Central and every scientist can read your work free of charge

"BioMed Central will be the most significant development for disseminating the results of biomedical research in our lifetime. "

Sir Paul Nurse, Cancer Research UK

Your research papers will be:

- available free of charge to the entire biomedical community

- peer reviewed and published immediately upon acceptance

- cited in PubMed and archived on PubMed Central

- yours - you keep the copyright

Submit your manuscript here:

http://www.biomedcentral.com/info/publishing_adv.asp 